$$
\begin{aligned}
& \text { بررسى تاثيرات خاكستر آتشفشانى كوه دماونف بر شاخص هاى رشلى و فيز.بولوز.بكى لوبيا } \\
& \text { رقيه حيدرى'، رامين عزتى ' و محمدعلى زاهد }
\end{aligned}
$$

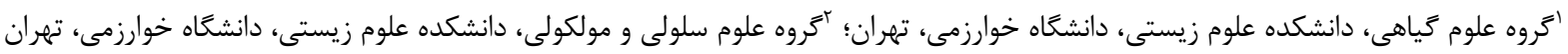

$$
\begin{aligned}
& \text { مسئول مكاتبات: رقيه حيدرى، std_Roghayehheydari71@khu.ac.ir }
\end{aligned}
$$

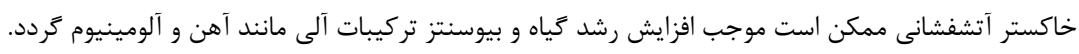

$$
\begin{aligned}
& \text { وازههاى كليدى. باقلائيان، تيماردهى، ويزَىىهاى مورفولوزى، قند محلول، يروتئين كل }
\end{aligned}
$$

\title{
The effects of Damavand volcanic ash on some morphological and physiological characteristics of Phaseolus vulgaris
}

\author{
Roghayeh Heydari ${ }^{1}$, Ramin Ezzati ${ }^{1}$ \& Mohammad Ali Zahed ${ }^{2}$ \\ ${ }^{1}$ Department of Plant Sciences, Faculty of Biological Sciences, Kharazmi University, Tehran, Iran; ${ }^{2}$ Department of Cell \\ and Molecular Sciences \\ Correspondent author: Roghayeh Heydari, std_Roghayehheydari71@khu.ac.ir
}

\begin{abstract}
The purpose of this study was to investigate the effect of Damavand volcanic ash on the morphological and physiological characteristics of beans as a factorial experiment in a completely randomized design. The results showed that the highest dry leaf weight was observed in $100 \mathrm{mg} / \mathrm{L}$ treatment per liter of volcanic ash $(0.0099 \mathrm{~g})$. The results also showed that the optimal sugar content of the soluble sugar at $100 \mathrm{mg} / \mathrm{L}$ of volcanic ash was 0.650 (mg/g D.W.). The highest protein content and optimal peroxidase activity were observed with 0.68 (mg/g F.W.) and 0.082 (A470/mg/protein), respectively. Therefore, it can be argued that volcanic ash may increase plant growth and biosynthesis of organic compounds such as iron and aluminum.
\end{abstract}

Keywords. Fabaceae, treatments, growth characteristics, soluble sugar, total protein 
تعادل بين عناصر غذايى يرمصرف و كممصرف، توليد در واحد سطح

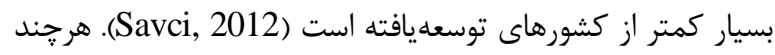

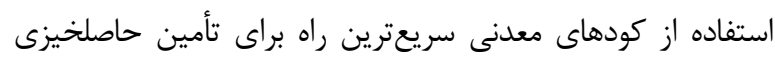

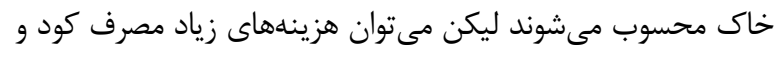

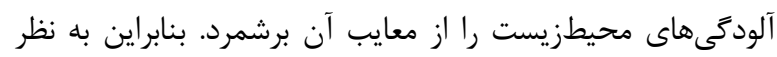

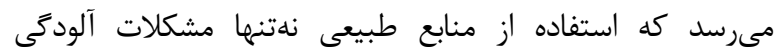

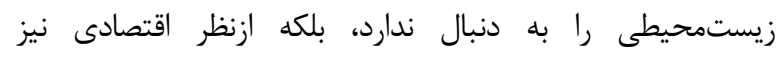
مقرونبهصرفه است (Laegreid et al., 1999). افزايش روزافزون

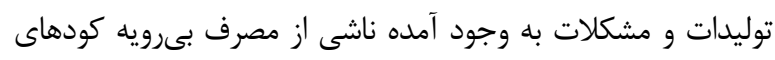

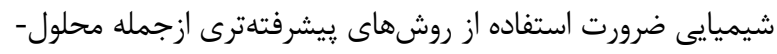

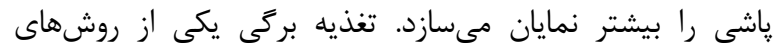

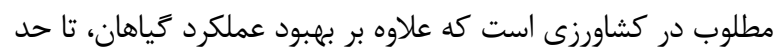
زيادى كاهش مصرف كودهاى شيميايى و خطرات زيست زيتمحيطى

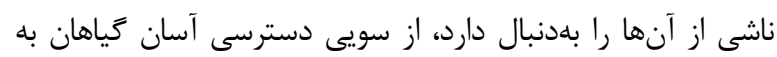

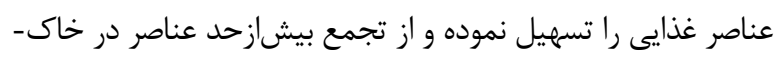
ها جلوكيرى مى كند (Sultana et al., 2018).

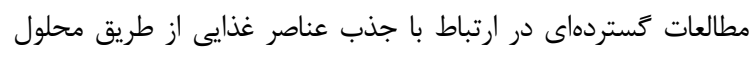

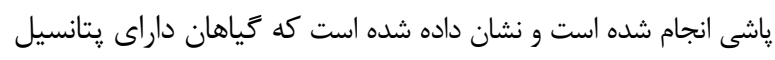

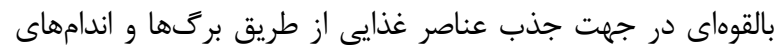

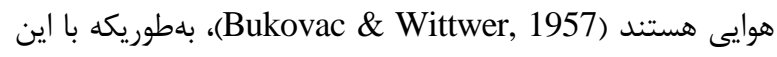

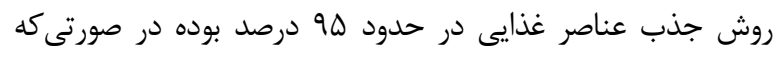

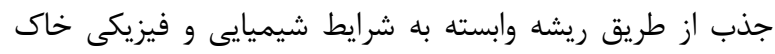

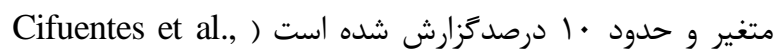
.2010 خاكهاى آتشفشانى داراى كاتيونهاى مختلفى ازجمله سديم،

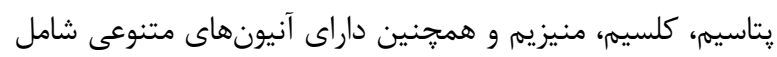

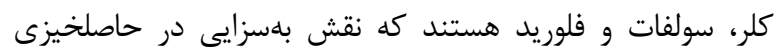
خاكهاى كشاورزى دارند (Chakrborty et al., 2015). خاكستر آتشفشانى مىتواند بلعنوان كود طبيعى براى كياهان مورداستفاده قرار كيرد (Nakagawa \& Ohba, 2003).

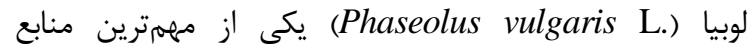

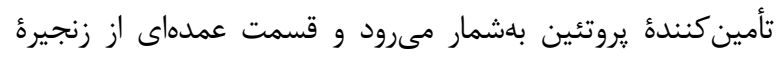

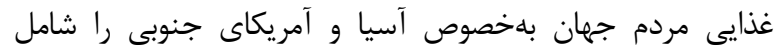

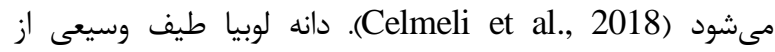

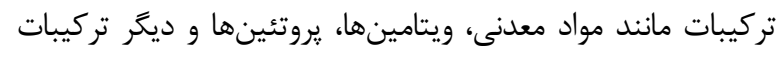

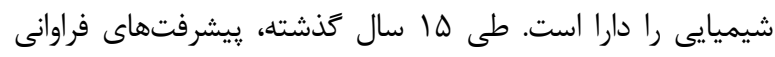

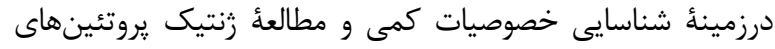
عمده ذخيرهاى لوبياى زراعى و خويشاوندان وحشى آن آن صورت

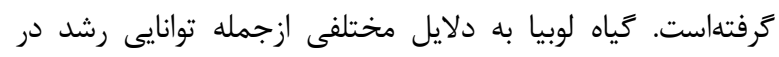

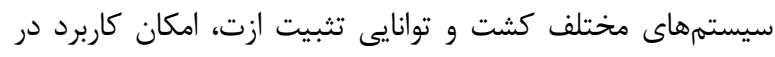

مقامله

ماكما جز فراوانترين مواد آتشفشانى است و اصطلاحى كلى براى توصيف قطعاتى از سنكهاى آتشفشانى و كدازمهايى با اندازمهاى

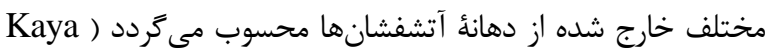

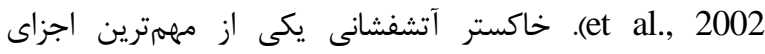

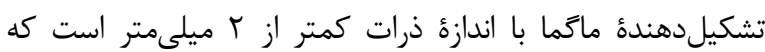
قطعات مواد معدنى، ليتيك و خردهشيشه را شامل مى شود. خاك-

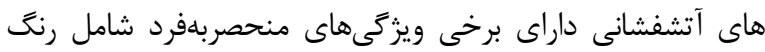

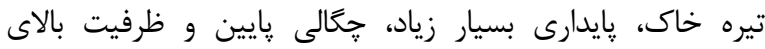

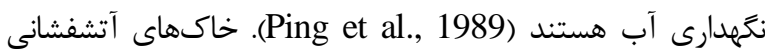
جوان داراى مقدار زيادى ماكرو يور يا روزنههاى بزرى در اندازههاى بيشتر از ·. إيكومتر و نيز مقدار كمترى از ميكرو يور در اندازئ

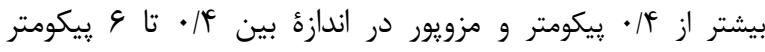

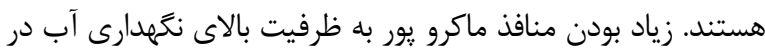

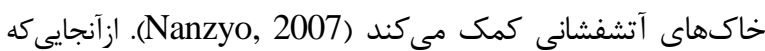

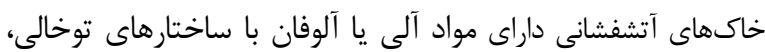

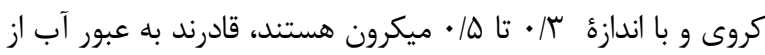

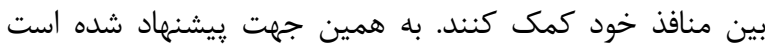

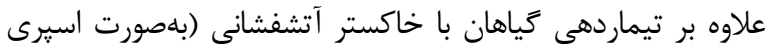

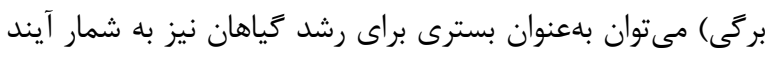
Parfit \& Wilson, 2008)

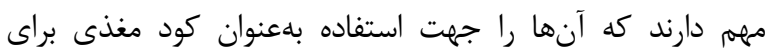

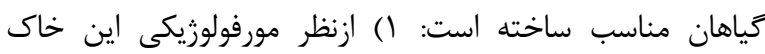

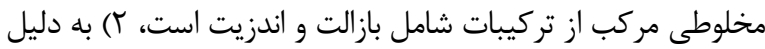

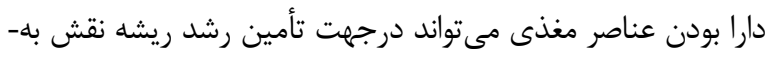

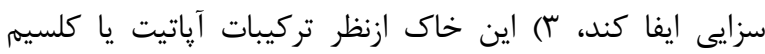

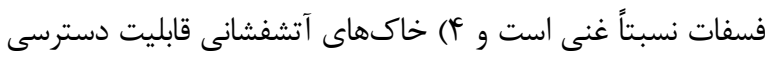

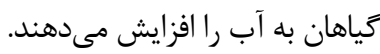

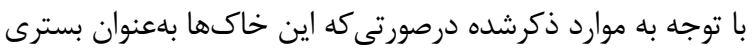

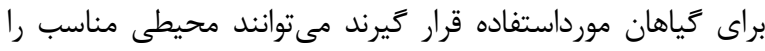

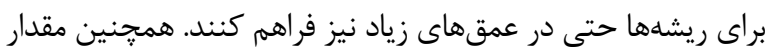

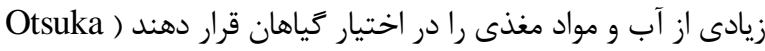
.et al., 1988 در دهأ كذشته مصرف كودهاى شيميايى، اثرات و رِيامدهاى

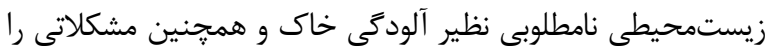

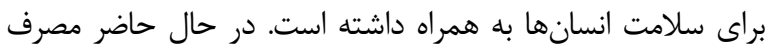

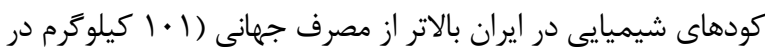

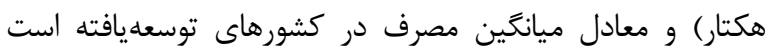
(· (11 كيلو گرم در هكتار)، اما عمدتاً به دليل عدم آكاهى كشاورزان،

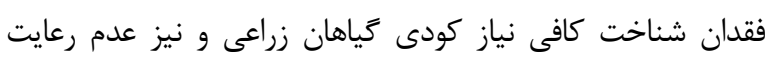


خاك (Bohn et al., 1979) انجام شد ضرورت اندازهگيرى به اين دليل است كه نقش تعيين كنندهاى در ارتباط باقابليت

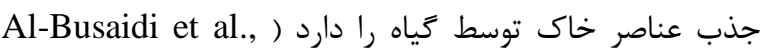

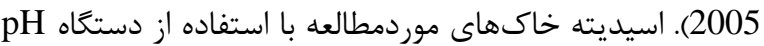

$$
\text { آمادرسازى محله روشلول هوكلنديد تعيين شد. }
$$

جهت تهيه محلول غذايى هوخلند از روش ارائهشده توسط

هوَّلند و آرنون (Hogland \& Arnon, 1950) استفاده شد.

سنجش ميزان قند محلول و يروتئين كل

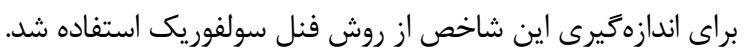

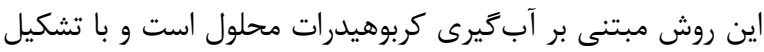

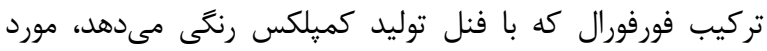
ارزيابى قرار گرفت. براى ارزيابى كربوهيدرات محلول، ابتدا با استفاده

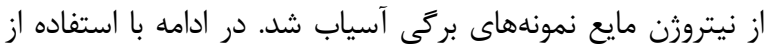

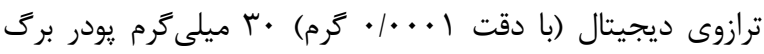
توزين و به آن ا ميلىليتر محلول اتانول •^ درصد اضافه كرديد.

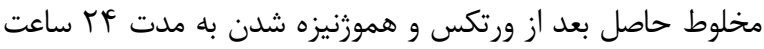

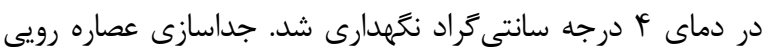

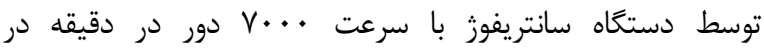

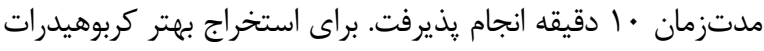

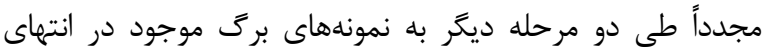

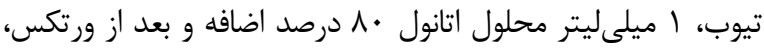

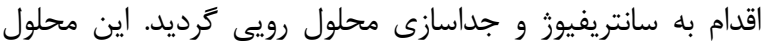

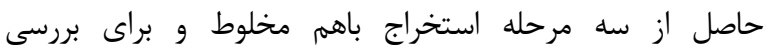

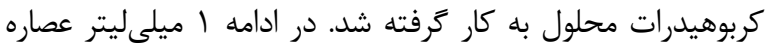

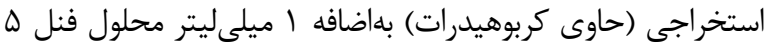

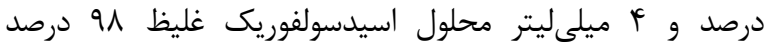

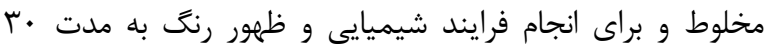
دقيقه در دماى اتاق قرار داده شد. با محلول •^ درصد اتانول

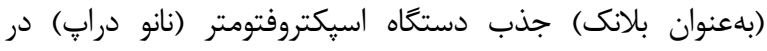

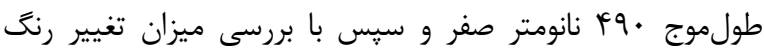
محلول واكنش، مقدار كربوهيدرات نمونههاى تحت تيمار و شاهد

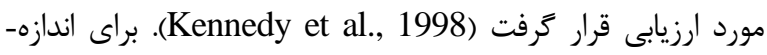
كيرى يروتئين كل از روش بردفورد (Bradford, 1976) استفاده

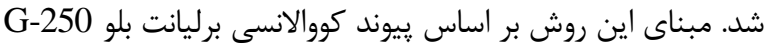

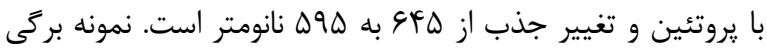

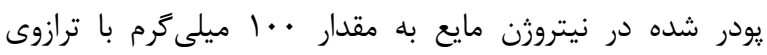

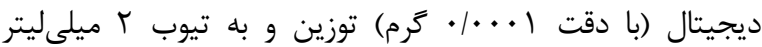

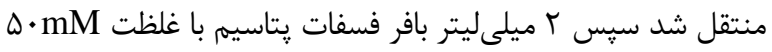
با pH برابر 1/ بإ به آن اضافه شد. جداسازى عصاره رويى توسط
كشاورزى بايدار، كم بودن ميزان مواد غيرمغذى، فقدان كلسترول در

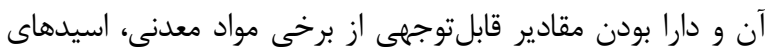

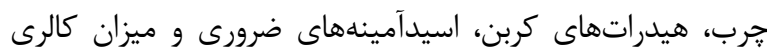
زياد نسبت به ساير باقلائيان در زنجيرء غذايى نقش بهسزايى دارد .(Augustin et al., 1981) اطلاعات دقيقى درزمينهُ مطالعة تأثيرات خاكستر آتشفشانى بر

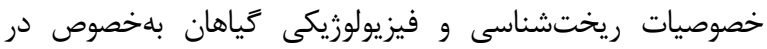

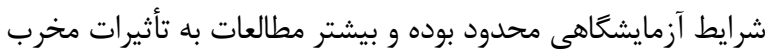

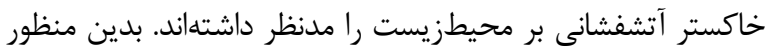

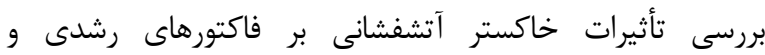

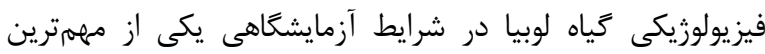
اهداف اين مقاله بوده است.

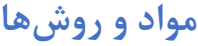

بلمنظور بررسى تأثير خاكستر آتشفشانى دماوند بر شاخصهاى روناي

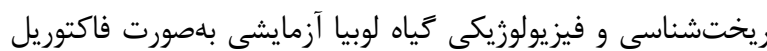

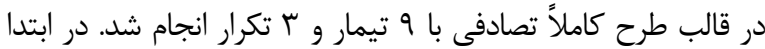

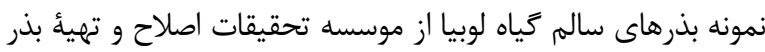
و نهال تهيه كرديد. تعدادى از بذرهاى سالم براى كاشت انتخاب

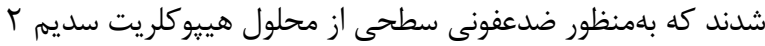
درصد استفاده شد. جهت كشت نمونه بذرهاى استريل شده از

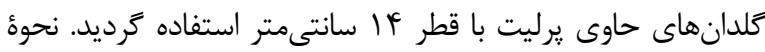

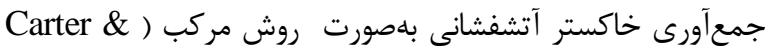
(Gregorich, 1998 نمونهبردارى از مناطق دستنخورده صورت كرفت. همجنين

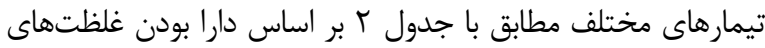
مختلف از عناصر موجود مورداستفاده قرار گرفت. در ادامه نمونههاى شاهد توسط محلول هوكلند مورد تيماردهى قرار كرفتند. تيمارها

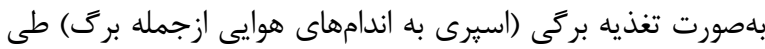

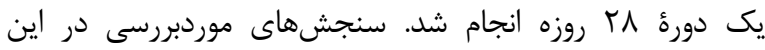
مطالعه شامل اندازميرى pH خاكستر آتشفانى و خاك دماوندي اندازمكيرى هدايت الكتريكى (EC) خاك، آناليز شيميايى خاك

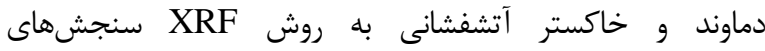

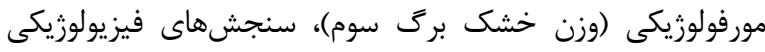

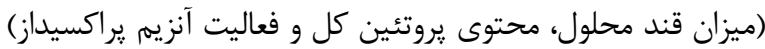

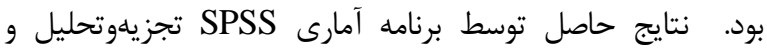

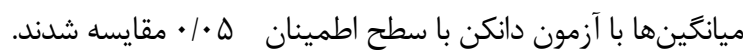

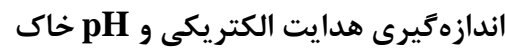
هدايت الكتريكى خاكهاى دماوند و خاكستر آتشفشانى با استفاده از دستكاه هدايت سنج الكتريكى و توسط روش ارائهشده 
اتم را آزاد مى كند و فضاهاى خالى در يوسته الكترونى اتمها

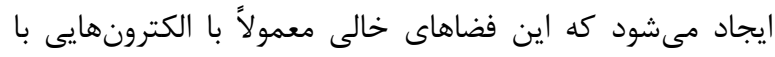

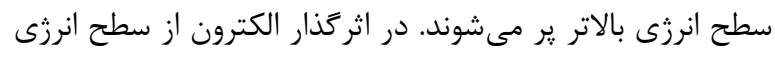

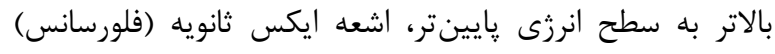

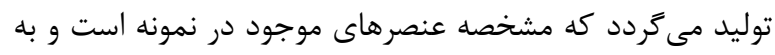

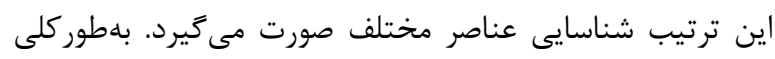

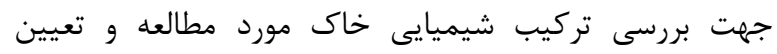

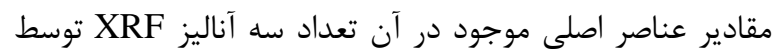

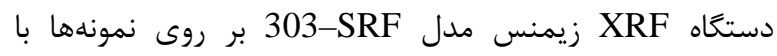
استفاده از روش ”Smykatz, 1974" انجام شد. نتايج حاصل از زاز اين سنجش در جدول آ آمده است.

\section{نتايج}

\section{هدايت الكتريكى و pH خاك}

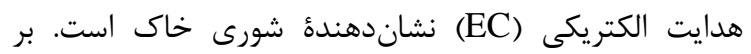

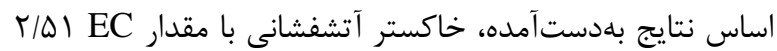

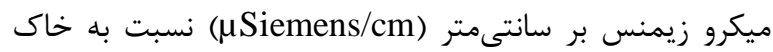

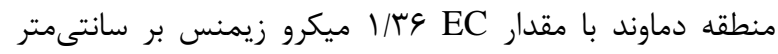

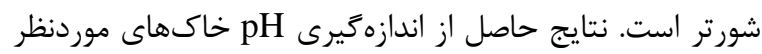

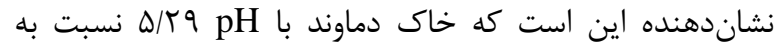

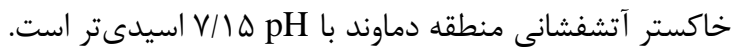
آناليز تركيبات غذايى هوكلند

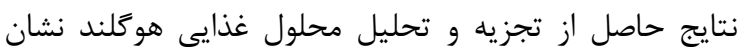

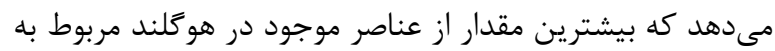

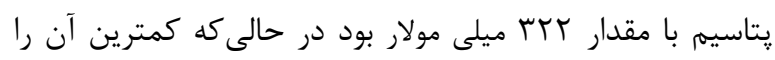

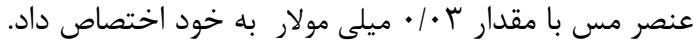

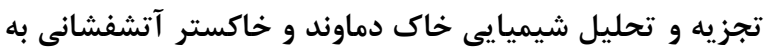
روش نتايج آناليز خاك دماوند و خاكستر آتشفشانى حاكى از آن

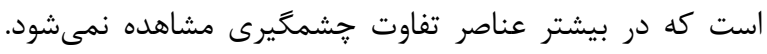

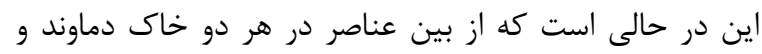

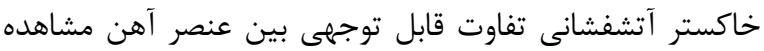

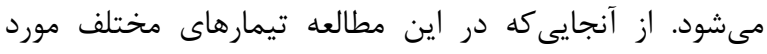

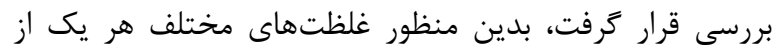

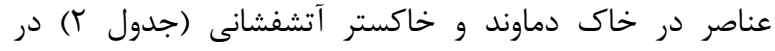
تيمارهاى مختلف بررسى شد. وزن خشك برك سوم كياه لوبيا تحت تيمارهاى خاك دماوند و خاكستر آتشفشانى

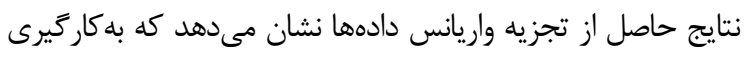

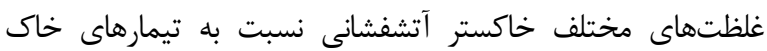

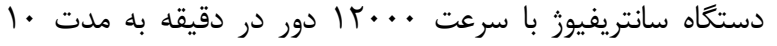
دقيقه در دماى \& أ درجه سلسيوس انجام كرديد.

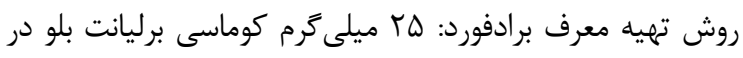

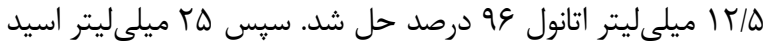

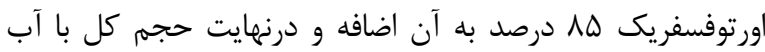

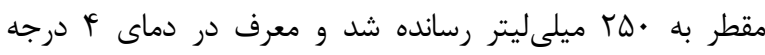

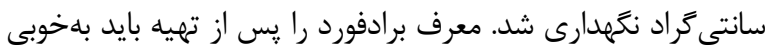

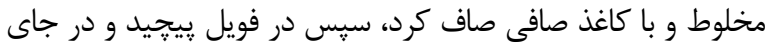

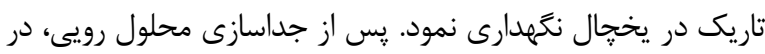

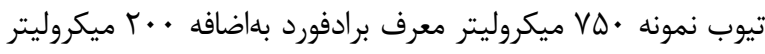

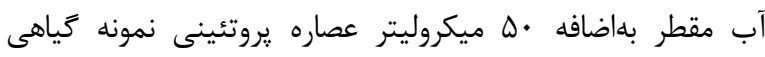

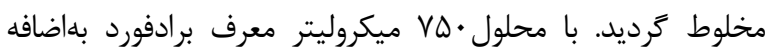

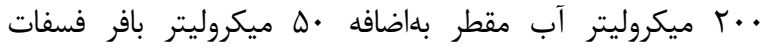

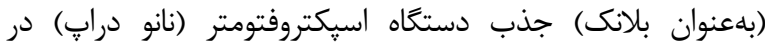

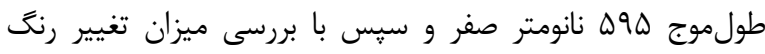

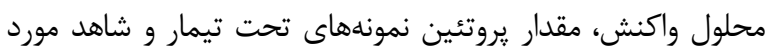
ارزيابى قرار كرفت (Bradford, 1976). سنجش فعاليت آنزيم براكسيداز

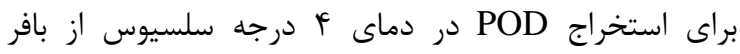

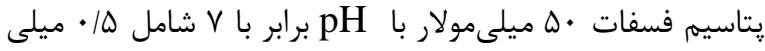

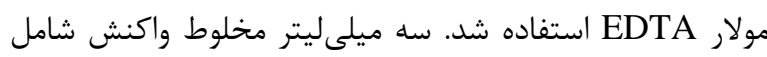

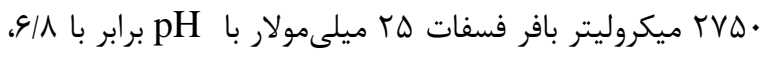

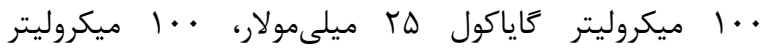

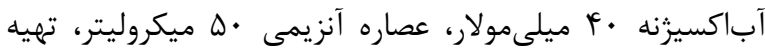

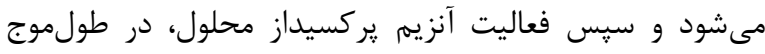
مجا نV.

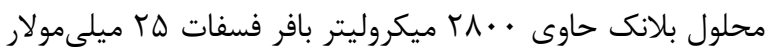

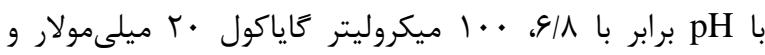

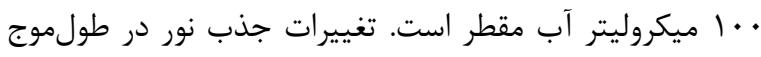
انانو \&V.

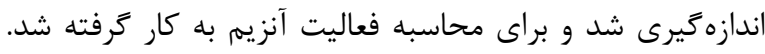

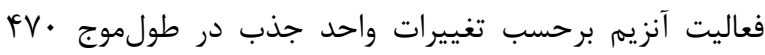

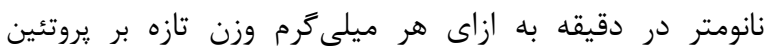

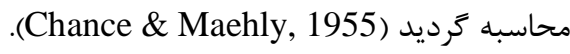

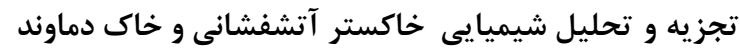

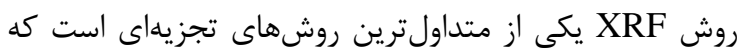

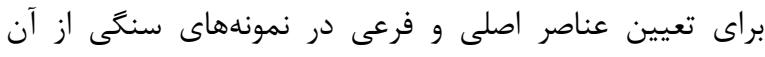

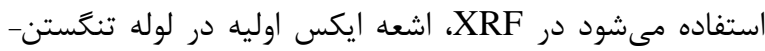

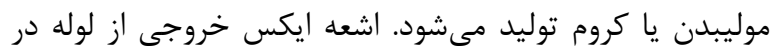

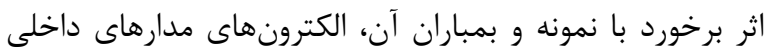


يروتئين كل برك لوبيا نشان مىدهد كه اختلاف معنى دارى در

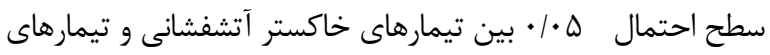

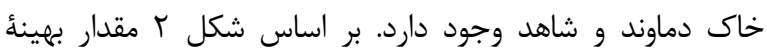
يروتئين در تيمار ..1 ميلى گرم در ليتر خاكستر آتشفشانى و كمترين ميزان آن در نمونه شاهد مشاهده مى شئود. سنجش آنزيم براكسيداز نتايج حاصل از واريانس دادههاى سنجش آنزئ آنزيم يراكسيداز

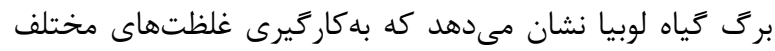

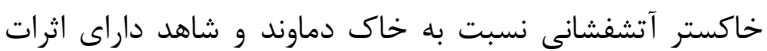

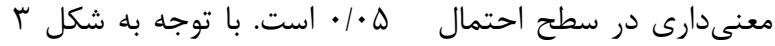

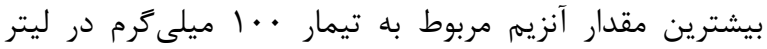
خاكستر آتشفشانى مشاهده شد، در حالى كه كمترين ميزان آنزيم در نمونه شاهد بهدست آمد.
دماوند و شاهد اثرات معنى دارى بر وزن خشك برك لوبيا در سطح احتمال $\geq$ ه.• داشته است. بر اساس نتايج بهدست آمده بيشترين وزن خشك مربوط به تيمار ..1 ميلى كرم در ليتر خاكستر آتشفشانى و كمترين آن مربوط به نمونه شاهد بود (شكل (1).

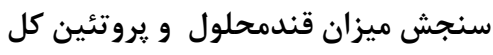

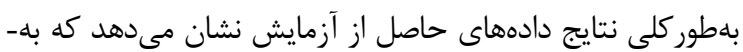
كاركيرى غلظتهاى مختلف خاكستر آتشفشانى بلهورت اسيرى

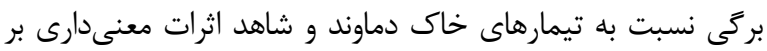

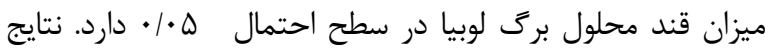

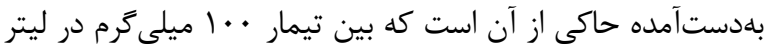

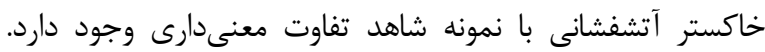

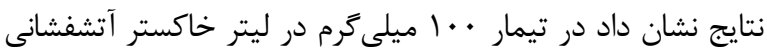

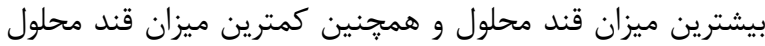

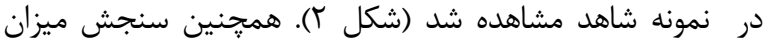

جدول اـ آناليز تركيبات معدنى خاكستر آتشفشانى و خاك دماوند به روش XRF.

Table 1. The analysis of minerals components of volcanic ash and Damavand soil by XRF method.

\begin{tabular}{ccc}
\hline Elements & Volcanic ash $(\%)$ & $\begin{array}{c}\text { Damavand soil } \\
(\%)\end{array}$ \\
\hline $\mathrm{Si}_{2} \mathrm{O}_{3}$ & 34.5 & 21.86 \\
\hline $\mathrm{Al}_{2} \mathrm{O}_{3}$ & 7.87 & 4.57 \\
\hline $\mathrm{BaO}$ & 0.23 & 0.05 \\
\hline $\mathrm{CaO}$ & 18.52 & 19.93 \\
\hline $\mathrm{Fe}_{2} \mathrm{O}_{3}$ & 29.35 & 3.76 \\
\hline $\mathrm{K}_{2} \mathrm{O}$ & 0.75 & 1.41 \\
\hline $\mathrm{MgO}$ & 3 & 3.67 \\
\hline $\mathrm{MnO}$ & 0.09 & 0.15 \\
\hline $\mathrm{Na}_{2} \mathrm{O}$ & 1.58 & 1.68 \\
\hline $\mathrm{P}_{2} \mathrm{O}_{5}$ & 0.1 & 0.19 \\
\hline $\mathrm{SO}$ & 0.63 & 1.48 \\
\hline $\mathrm{Ti}_{2} \mathrm{O}$ & 0.33 & 0.52 \\
\hline $\mathrm{Cr}_{2} \mathrm{O}_{3}$ & 0.05 & 0.04 \\
\hline $\mathrm{LoI}$ & 18.86 & 24.68 \\
\hline $\mathrm{Sr}$ & 0.08 & 0.1
\end{tabular}

جدول r- بر بـى ميزان غلظت هريك از عناصر در تيمارهاى خاكستر آتشفشانى و خاك دماوند.

Table 2. The concentration of elements in volcanic ash and Damavand soil.

\begin{tabular}{|c|c|c|c|c|c|c|c|c|}
\hline \multirow[t]{2}{*}{ Elements } & \multirow[b]{2}{*}{ V10 } & \multirow[b]{2}{*}{ V30 } & \multicolumn{5}{|c|}{ Treatments } & \multirow[b]{2}{*}{ D100 } \\
\hline & & & V50 & V100 & D10 & D30 & D50 & \\
\hline $\mathrm{Si}_{2} \mathrm{O}_{3}$ & 3.4 & 10.3 & 17.2 & 34.5 & 2.1 & 6.5 & 10.9 & 21.8 \\
\hline $\mathrm{Al}_{2} \mathrm{O}_{3}$ & 0.7 & 2.3 & 3.9 & 7.8 & 0.4 & 1.3 & 2.2 & 4.5 \\
\hline $\mathrm{BaO}$ & 0.02 & 0.06 & 0.1 & 0.2 & 0.05 & 0.01 & 0.02 & 0.05 \\
\hline $\mathrm{CaO}$ & 1.8 & 5.5 & 9.2 & 18.5 & 19 & 5.9 & 9.9 & 19.9 \\
\hline $\mathrm{Fe}_{2} \mathrm{O}_{3}$ & 2.9 & 8.8 & 14.6 & 29.3 & 3 & 1.1 & 1.8 & 3.7 \\
\hline $\mathrm{K}_{2} \mathrm{O}$ & 0.07 & 0.22 & 0.37 & 0.75 & 0.14 & 0.42 & 0.70 & 1.41 \\
\hline $\mathrm{MgO}$ & 0.3 & 0.9 & 1.5 & 3 & 3 & 1.1 & 1.8 & 3.6 \\
\hline $\mathrm{MnO}$ & 0.009 & 0.027 & 0.045 & 0.09 & 0.015 & 0.045 & 0.075 & 0.15 \\
\hline $\mathrm{Na}_{2} \mathrm{O}$ & 0.15 & 0.47 & 0.79 & 0.15 & 0.16 & 0.50 & 0.84 & 1.68 \\
\hline $\mathrm{P}_{2} \mathrm{O}_{5}$ & 0.01 & 0.03 & 0.05 & 0.1 & 0.019 & 0.057 & 0.095 & 0.19 \\
\hline $\mathrm{SO}_{3}$ & 0.063 & 0.18 & 0.31 & 0.63 & 0.14 & 0.44 & 0.84 & 1.68 \\
\hline $\mathrm{Ti}_{2} \mathrm{O}$ & 0.033 & 0.099 & 0.165 & 0.33 & 0.052 & 0.156 & 0.26 & 0.52 \\
\hline $\mathrm{Cr}_{2} \mathrm{O}_{3}$ & 0.005 & 0.015 & 0.025 & 0.05 & 0.004 & 0.012 & 0.02 & 0.04 \\
\hline LoI & 1.88 & 5.65 & 9.43 & 18.86 & 2.46 & 7.40 & 12.34 & 24.68 \\
\hline $\mathrm{Sr}$ & 0.008 & 0.024 & 0.04 & 0.08 & 0.01 & 0.03 & 0.05 & 0.1 \\
\hline
\end{tabular}




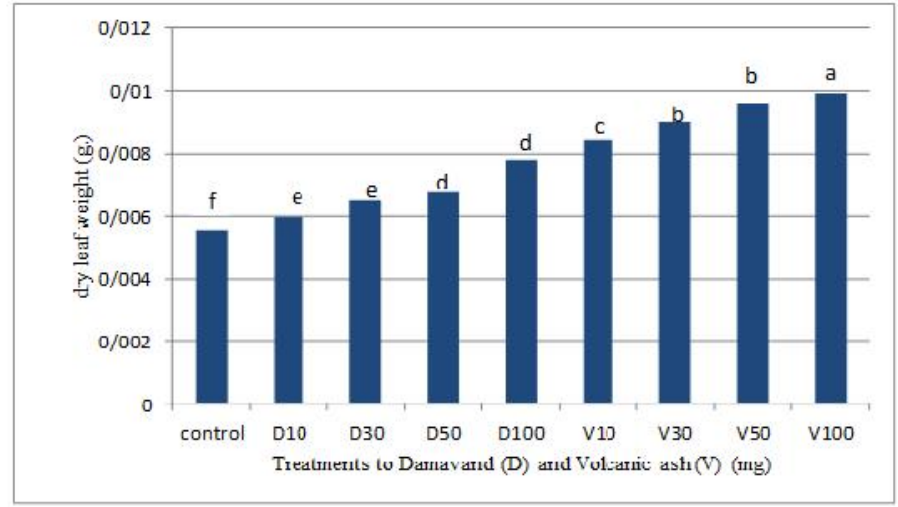

شكل ا- تغييرات وزن خشك برى گياه لوبيا در حضور تيمار اسيرى بركى با خاكستر آتشفشانى و خاك دماوند.

Fig. 1. Changes in dry weight of bean leaves in the presence of leaf spray treatment with volcanic ash and damavand soil.

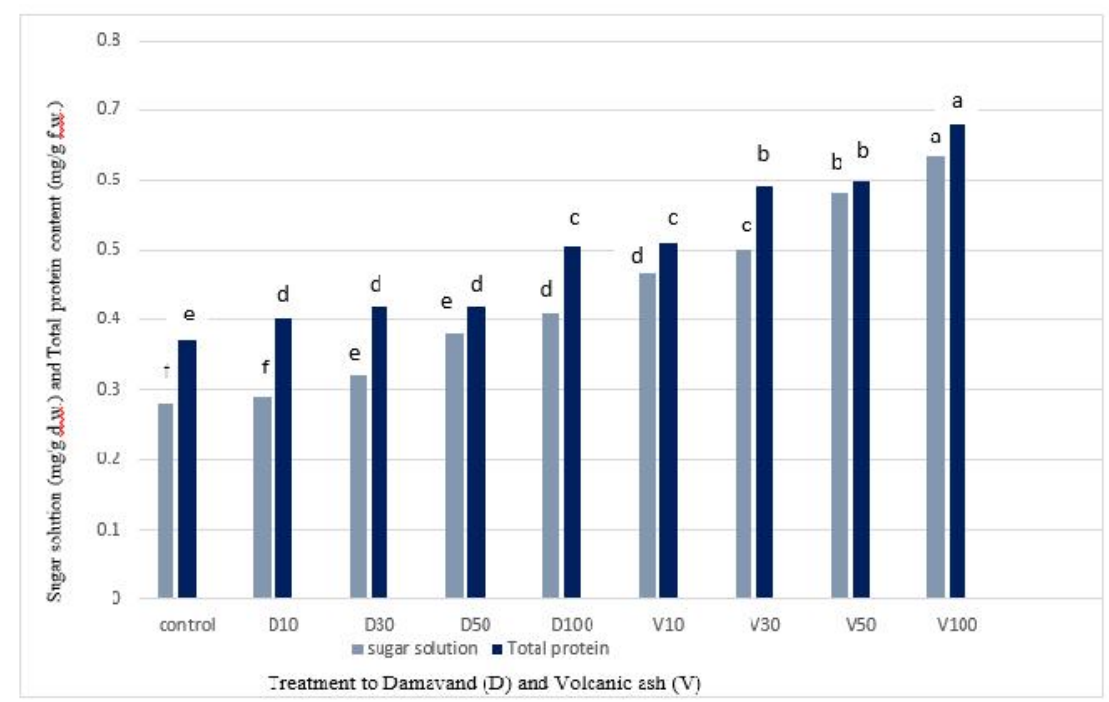

شكل r- تغييرات قندمحلول و يروتئين كل برى گياه لوبيا در حضور تيمار اسيرى بركى با خاكستر آتشفشانى و خاك دماوند.

Fig. 2. Changes in sugar solution and total protein of bean leaves in the presence of leaf spray treatment with volcanic ash and damavand soil.

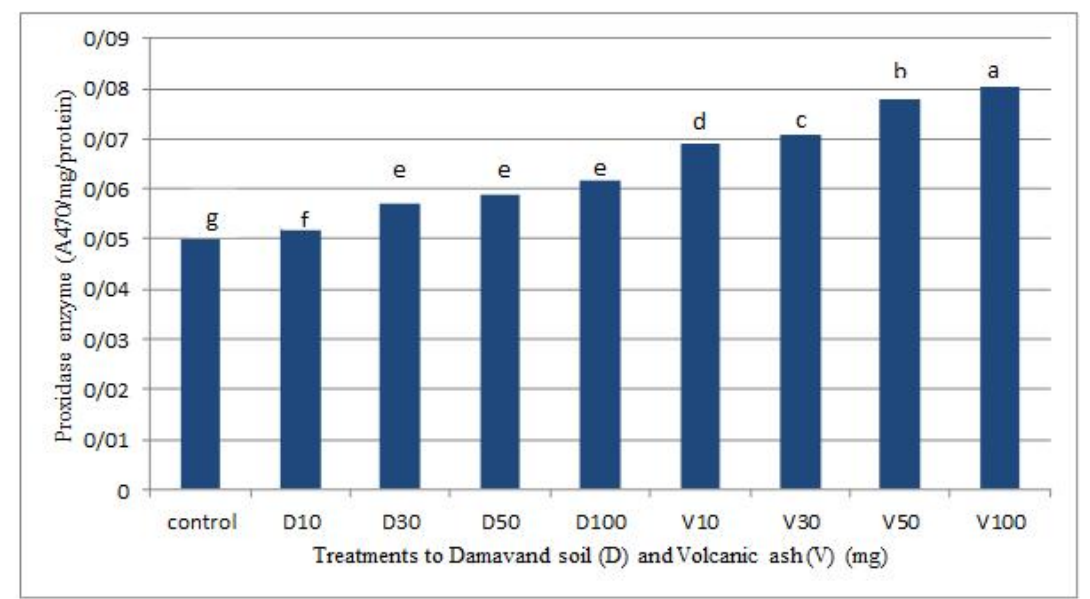

شكل بـ- تغييرات آنزيم يراكسيداز برى گياه لوبيا در حضور تيمار اسيرى برگى با خاكستر آتشفشانى و خاك دماوند.

Fig. 3. Changes of peroxidase enzymes in the presence of leaf spray treatment with volcanic ash and damavand soil. 
قندهاى محلول موجود در كياهان شده كه اين امر مكانيسمى براى تحريك رشد كياه مىشود ( Maksimovich et al., (2010 محققان بر اين باورند كه ديواره سلولى محل اصلى تجمع تعدادى از ايزو آنزيمهاى يراكسيداز است، همجنين مطالعات دهات نشان مى دهد كه ساخت و تراوش يراكسيدازهاى آيويلاستى كه إنه از قبل وجود داشتند، مىتوانند از طريق تغيير شرايط محيطى

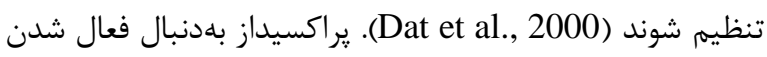

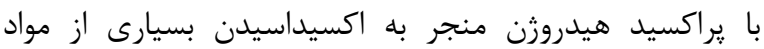

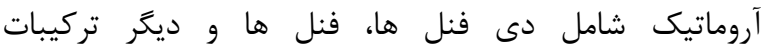
هتروآروماتيك مىشود (Klibanov et al., 1983). براساس آناليز تركيبات معدنى موجود دود درو خاكستر آتشفشانى و

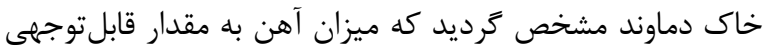

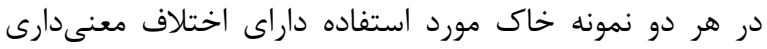
است. ازآنجايى كه آهن يكى از عناصر ضرورى و كممصرف كياه

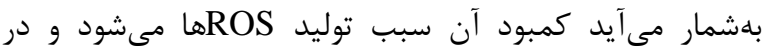

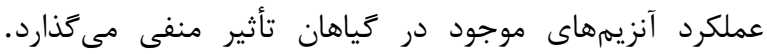

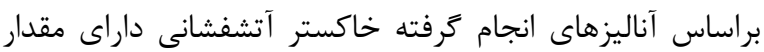

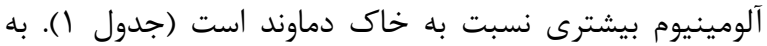

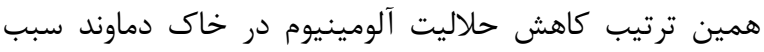

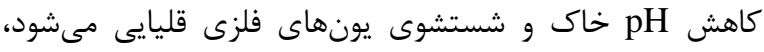
همجنين افزايش ميزان قند محلول وابستكى مستقيمى به إنه

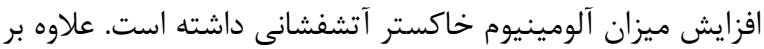

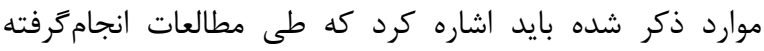
سيليس بهعنوان يكى از فراوانترين تركيبات موجود در خاكستر

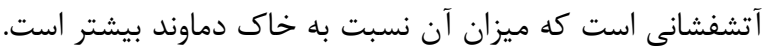

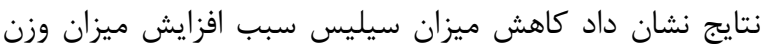

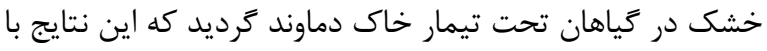
مطالعات قبلى (Kaya et al., 2002) مطابقت داشت.

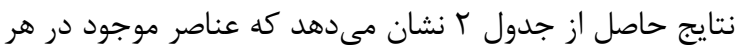

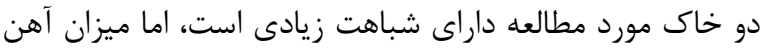
موجود در خاكستر آتشفشانى نسبت به خاك داى دماوند داراى

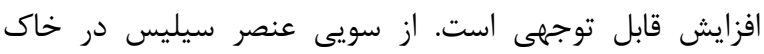

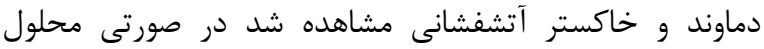

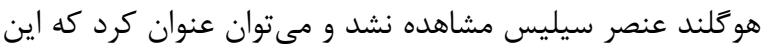

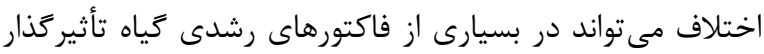
باشد (Rout \& Sahoo, 2015). بهطور كلى در برخى از مطالعات

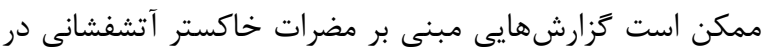

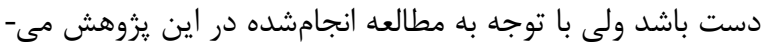

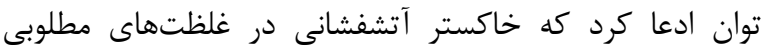

بحث

يزوهشكَران بيان داشتند كه انفجارهاى آتشفشانى موجب افزايش رشد طولى Nothofagus pumilio در نزديكى آتشفشان

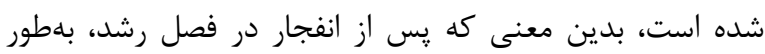

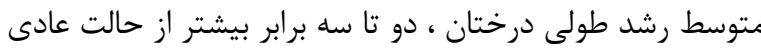
مشاهده شد در حالى كه تغييرات در رشد شعاعى بعد از فوران

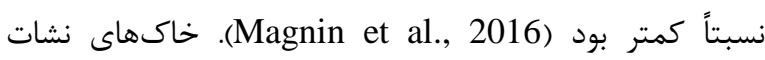
كرفته از مواد آتشفشانى داراى قابليت حاصلخيزى بالايى هستند

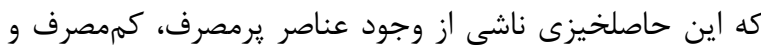

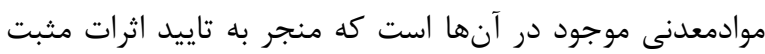
خاكستر آتشفشانى بر رشد كياهان شده است كه با ندان انتايج

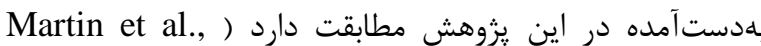
(2009 طى جند سال اخير مطالعات متعددى در ارتباط با تأثير غلظتهاى مختلف هيدروزن بر ميزان جذب عناصر غذايى خاك

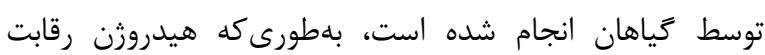

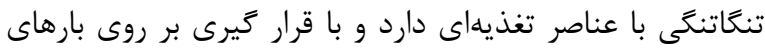

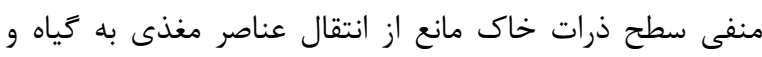

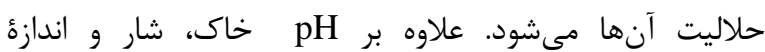
مولكولهاى مواد مغذى سبب محدوديت دسترسى كياهان به انهان

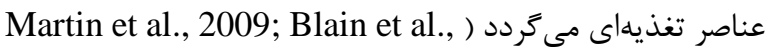

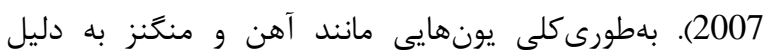

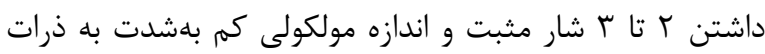

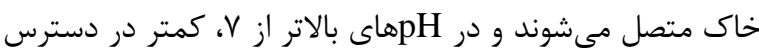

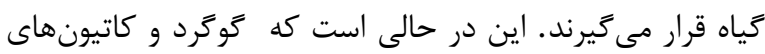

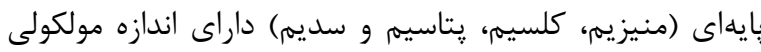

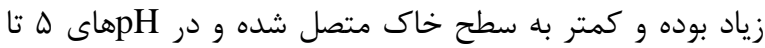

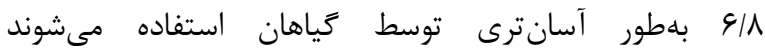
.(McCauley et al., 2017)

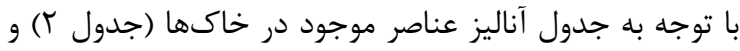

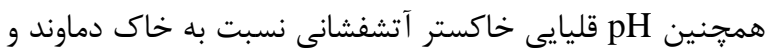

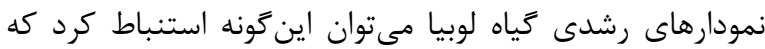

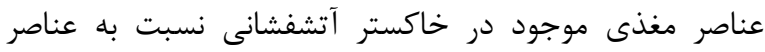

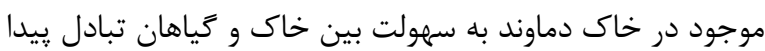

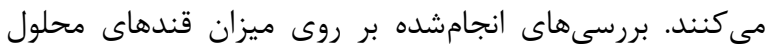

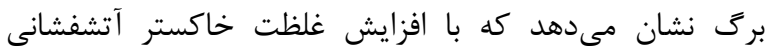

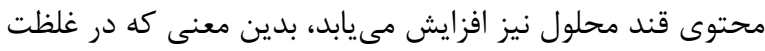

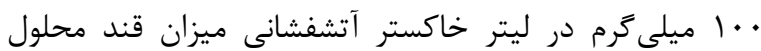

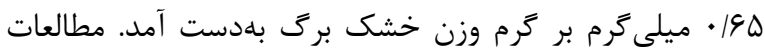

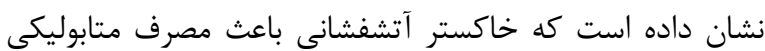




\section{REFERENCES}

Al-Busaidi, A., Cookson, P. \& Yamamoto, T. 2005. Methods of soil $\mathrm{pH}$ determination in calcareous soils: use of electrolyte and suspension effect. Australian Journal of Soil Research 43: 541- 545.

Augustin, J., Beck, C.B., Kalbfleish, G., Kagel, L.C. \& Matthews, R.H. 1981. Variation in the vitamin and mineral content of raw and cooked commercial Phaseolus vulgaris classes. Journal of Food Science 46: 1701-1706.

Blain, S., Qu'eguiner, B., Armand, L., Belviso, S., Bombled, B., Bopp, L., Bowie, A., Brunet, C., Brussaard, C., Carlotti, F., Christaki, U., Corbi'ere, A., Durand, I., Ebersbach, F., Fuda, J.L., Garcia, N., Gerringa, L., Griffiths, B., Guigue, C., Guillerm, C., Jaquet, S., Jeandel, C., Laan, P., Lef'evre, D., Monaco, C. L., Malits, A., Mosseri, J., Obernosterer, I., Park, Y.-H., Picheral, M., Pondaven, P., Remenyi, T., Sandroni, V., Sarthou, G., Savoye, N., Scouarnec, L., Souhaut, M., Thuiller, D., Timmermans, K., Trull, T., Uitz, J., van Beel, P., Veldhuis, M., Vincent, D., Viollier, E., Vong, L. \& Wagener, T. 2007. Effect of natural iron fertilization on carbon sequestration on the Southern Ocean. Nature 446: 1070-1074.

Bohn, H.L., McNeal, B.L. \& Connor, G.A. 1979. Soil chemistry. John Wiley \& Sons, New York.

Bukvac, M. \& Wittwer, S. 1957. Absorption and mobility of foliar applied nutrients. Plant Physiology 32: 428- 35.

Bradford, M.M. 1976. A rapid and sensitive method for the quantitation of microgram quantities utilizing the principle of protein-dye binding. Analytical Biochemistry 72: 248-254.

Carter, M.R., Angers, D.A. \& Kunelius, H.T. 1998. Soil structural and stability, and organic matter under cool season perennial grasses. Soil Science Society of America Journal 58: 1194-1199.

Celmeli, T., Sari, H., Canci, H., Sari, D., Adak, A., Eker, T. \& Toker, C. 2018. The nutritional content of common bean (Phaseolus vulgaris L.) landraces in comparison to modern varieties. Agronomy Journal 8: 166.

Chakraborty, K. \& Mistri, B. 2015. Soil fertility and its impact on agricultural productivity: a study in sapar mouza, burdwan-I C.D. Block, West Bengal. International Journal of Humanities \& Social Science Studies 2: 196-206.

Cifuentes, Z., Custardoy, L., Fuente, J., Marquina, C., Lbarra, M., Rubiales, D. \& Peres-de-Luque, A. 2010. Absorption and translocation to the aerial part of magnetic carbon-coated nanoparticles through the root of different crop plants. Journal of Nanibiotechnology 8: 26.

Dat, J., Vandenabeele, S., Vranová, E., Van Montagu, M., Inzé, D. \& Van Breusegem, F. 2000. Dual action of active oxygen species during plant stress responses. Cellular and Molecular Life Science 57: 779-795.

Hoagland, D.R. \& Arnon, D. 1950. The water culture method for growing plants without soil. COA, California, 500 pp.

Kaya, C., Kirnak, H. \& Saltali, K. 2002. Supplementary calcium enhances plant growth and

$$
\begin{aligned}
& \text { بهعنوان كود مغذى براى گياهان بهشمار مى آيد. همجنين در }
\end{aligned}
$$

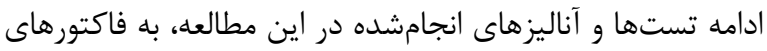

$$
\begin{aligned}
& \text { زايشى كياهان مختلف تحت تأثير خاكستر آتشفشانى و فعاليت } \\
& \text { آنزيمهاى آنتىاكسيدانى ديكر مانند كلوتاتيون و آسكوربات و } \\
& \text { موارد ديگر نيز مىتوان زيرداخت. }
\end{aligned}
$$

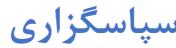

$$
\begin{aligned}
& \text { فدينوسيله از معاونت يزوهش و فناورى دانشگاه خوارزمى براى }
\end{aligned}
$$

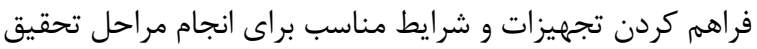

$$
\begin{aligned}
& \text { قدردانى مىشود. }
\end{aligned}
$$


$(\mathrm{NaCl})$ salinity. Scientia Holticulturae 93: 65-74.

Kennedy, M.J., Chadwick, O.A., Vitousek, P.M., Derry, L.A. \& Hendricks, D.M. 1998. Replacement of weathering with atmospheric sources of base cations during ecosystem development, Hawaiian Island. Geology 26: 1015-8.

Klibanov, A.M., Tu, T.M. \& Scott, K.P. 1983. Peroxidase catalyzed removal of phenols from coalconversion wastewaters. Science 221: 259.

Kuznetsov, V.V. \& Shevyakova, N.I. 1977. Stress responses of tobacco cells to high temperature and salinity. proline accumulation and phosphohydration of polypeptids. Physiologia Plantarum 100: 320-326.

Laegreid, M., Böckman, O.C. \& Kaarstad, O. 1999. Agriculture, fertilizers and the environment. CABI Publishing in association with Norsk Hydro ASA, 150 pp.

Maehly, A.C. \& Chance, B. 1954. The assay of catalases and peroxidases. Methods of Biochemical Analysis 1: 357-424.

Magnin, A., Villalba, R., Torres, C.D., Stecconi, M., Passo, A., Sosa, C.M. \& Puntieri, J.G. 2016. Effect of volcanic ash deposition on length and radial growths of a deciduous montane tree (Nothofagus pumilio). Austral Ecology 42: 103-112.

Maksimović, I., Putnik-Delić, M., Gani, I., Marić, J. \& Ilin, Z. 2010. Growth, ioncomposition and stomatal conductance of peas exposed to salinity. Central European Journal of Biology 5: 682- 691.

Martin, R.S., Watt, S.F.L., Pyle, D.M., Mathet, T.A., Matthews, N.E., Georg, R.B., Day, J.A., Fairhead, T., Witt, M.L.I. \& Quayle, B.M. 2009. Environmental effects of ash in argentina from the 2008 Chaitén volcanic eruption. Journal of Volcanology and Geothermal Research 184: 462-472. fruit yield in strawberry cultivars grown at high

McCauley, A., Jones, C. \& Olson kutz, K. 2017. Soil $\mathrm{pH}$ and organic matter. Journal of Geoscience and Environment Protection 6: 194-210.

Nakagawa, M. \& Ohba, T. 2003. Minerals in volcanic ash 1: primary minerals and volcanic glasses. Enviromental Research 6: 41-51.

Nanzyo, M. 2007. Introduction studies on volcanic ash soils in Japan and international collaboration. Journal of Integrated Field Science 4: 71-77.

Otsuka, H., Briones, A.A., Daquiado, N.P. \& Evangelio, F.A. 1988. Characteristics and genesis of volcanic ash soils in the Philippines. Technical Bulletin. Tropical Agriculture Research Center: Japan 24: 1-127.

Parfitt, A.E. \& Wilson, L. 2008. Fundamentals of physical volcanology. Oxford, UK, Blackwell Publishing, 230 pp.

Ping, C.L., Shoji, S., Ito, T., Takahashi, T. \& Moore, J.P. 1989. Characteristics and classification of volcanic ash derived soils in Alaska. Soil Science 148: 8-28. Rout, R. \& Sahoo, S. 2015. Role of iron in plant growth and metabolism. Reviews in Agricultural Science 3: 1-24.

Savci, S. 2012. An agriculture pollutant: chemical fertilizer. International Journal of Environmental Science and Development 3: 77-80.

Sultana, S., Mohammad Naser, H., Quddus, A. \& Shill, N. 2018. Effect of foliar application of iron and zinc on nutrient uptake and grain yield of wheat under different irrigation regimes. Bangladesh Journal of Agricultural Research 43: 395.

Symkatz, K.W. 1974. Differential thermal analysis, application and results in mineralogy. Springer Verlag, Berlin, pp: 81-90.

How to cite this article:

Heydari, R., Ezzati, R. \& Zahed, M.A. 2020. The effects of Damavand volcanic ash on some morphological and physiological characteristics of Phaseolus vulgaris. Nova Biologica Reperta 7: 346-354. (In Persian).

$$
\begin{aligned}
& \text { حيدرى، ر.، عزتى، ر. و زاهد، م.ع. وجس ا. بررسى تأثيرات خاكستر آتشفشانى كوه دماوند بر شاخصهاى رشدى و فيزيولوزيكى لوبيا. يافتهاى نوين }
\end{aligned}
$$

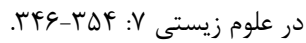

